\title{
Fanconi Anemia Complementation Group Protein
}

National Cancer Institute

\section{Source}

National Cancer Institute. Fanconi Anemia Complementation Group Protein. NCI

Thesaurus. Code C85881.

A protein that is a member of a structurally diverse group that forms a protein complex which may regulate both DNA repair and the cell cycle. Mutation of any member of this group may inhibit the formation of the complex and is associated with Fanconi anemia. 